\title{
Evaluating the Site of Avrocity as a High-Rise Residential Project in Duhok City According to LEED Sustainable Rating Criteria
}

\author{
By Riman Dhuoki ${ }^{1}$, Çiğdem Çağnan ${ }^{2}$
}

\begin{abstract}
Duhok city faced many challenges in the last decades because of urban and population growth especially in the residential sector because there is shortage in providing housing units annually. Highrise residential projects are one of the common solutions to overcome the deficit. Yet, these kinds of residential projects have many issues since it is a new method of development within the city. From here the main aim of this study come to light which is to improve the quality of high-rise residential projects site in accordance to sustainable rating system and establish effective regulations framework with the help of internationally accepted criteria. The reason for upgrading the regulations is that the sites of these projects do not offer healthy built environment to their residents. The lack of nearby social and technical infrastructures caused more distances to be covered by vehicles resulting environmental pollution which could cause global warming. To investigate and evaluate the high-rise residential projects site according to Leadership in Energy and Environmental Design (LEED) sustainable rating tool, a residential project site has been chosen, which is; Avrocity project. The information had been analyzed qualitatively. The obtained results demonstrated that, the lack of updated regulations in Duhok city lead to improper planning and deficiency of services within residential projects site.
\end{abstract}

Keywords: Dubok city; sustainability; LEED; Avrocity; high-rise residential projects site; location and transportation

\section{Introduction}

Due to environmental issues such as environmental pollution and global warming, scholars are seeking for solutions to guarantee sustainability (Aljenbaz and Çağnan, 2020). The necessity to control the global warming and climate change, which the world facing it in $21^{\text {st }}$ century, requires the action towards sustainability are essential issues nowadays (Shawkat et al., 2018). Across the world, buildings are using primary energy up to $30 \%$ to $40 \%$. Therefore, solutions need to be adapted to local conditions because the different countries have disparity in environment, economic and social conditions (UNEP, 2007). Activities of urban development have been quickened since Industrial Revolution and become one of major causes of environmental crisis that humankind is facing (Y1ldirim et al., 2020). The rapid growth of population in Iraq's cities due to migration from other part of the country and moving from rural parts to urban areas led to increase of urbanization and industrialization in cities. Duhok as one example of these cities face a lot of social, economic and environmental challenges in the last decades. The increase of population 
caused request of accommodation and this led to dramatic investment in residential sector especially in high-rise residential projects. This dramatic development lead to excessive consumption of material, energy, water, land use etc. without awareness of its negative impact on environment and human well-being. The sustainable building is any build structure that is environmentally friendly and does not have impact on climate change. The analysts agree that the growth in urban areas raised the request of high-rise residential living, but the matters that are forefront to be focused on are; life-style, health, environmental awareness and sustainability. These matters are not only altering the way people live but effecting and reinventing how stakeholders build high-rise residential projects (Kaplan, 2007). Despite of sustainable green buildings in residential sector of Duhok are not existing, still the high-rise residential projects are the decent solution to overcome the shortage of housing units demand that the city is facing. On the other hand, the impropriate planning and design with the lack of constructions legalizations and codes of these projects' results problems of infrastructure, open green space, transportation, land use, human activities etc. In the last thirty years, the world community is concerning extremely on the environmental issues such as global warming and increasing the consumption of non-renewable resources. Therefore, various sustainable rating systems has been established to achieve the goals of sustainable building and its environment. The well-known systems such as LEED (Leadership in Energy and Environmental Design) in the United States of America (USA) and BREEAM (Building Research Establishment Environmental Assessment Method) in the United Kingdom (UK) are the leading sustainable rating systems in this scope. However, Iraq as a country has not been advanced any sustainable criteria or rating systems for either residential or commercial buildings based on existing world leading sustainable rating systems. Additionally, the concept of sustainability is not taken into consideration in Duhok and it is counted as not existing. Whatever future holds for environment, the high-rise residential projects must become sustainable considering the long-term economic growth, human needs and environment (Ali and Armstrong, 2008).

The high-rise residential projects are conventional buildings and using nonrenewable resources. The site design of these projects is not helping to be a walkable environment and do not provide strong infrastructure that meet the needs of the occupants. On the other hand, these projects lack of build standards and regulations that are compulsory in any buildable environment to provide better, healthier and safer environment for the users. This study attempts to overview the importance and advantage of applying sustainable methods in residential sector especially in high-rise residential projects site. This is done by assessing developed countries that have adopted the concept and have reaped the benefits from applying sustainable methods. The significance of this paper is to come up with sustainable design criteria and applications in site of high-rise residential projects that can be suitable for local conditions in Duhok city depending on existing sustainable systems such LEED V4.1 (BD+C Multifamily Homes) rating system. Additionally, to overcome the lack of services such electricity shortage that the city is facing in general and residential projects in specific. Sustainable residential project is not a luxurious step in residential sector but it is a need for better daily life in Duhok city. The aim of the research is to shed light on residential sector, by analyzing the present situation and difficulties the site of high-rise residential projects is facing according to general concept of sustainability 
in Duhok city and to address the alternative solutions that are reliable according to sustainable development. Investigating and evaluating the site of high-rise residential projects in accordance to criteria and architectural designs of LEED V4.1 (BD+C Multifamily Homes) to meet the sustainable necessity in such projects. As well as, propose several sustainable criteria and codes that will be essentials to improve the site of high-rise residential projects in Duhok city according to LEED sustainable rating system. The paper exclusively studies the implementation of sustainable architecture regulations and standards locally in the city, via evaluating practices context. The study is limited on the site of high-rise residential projects in Duhok city. Also, it scopes on the sustainable rating tool (Leadership in Energy and Environmental Design Version 4.1 for Building Design and Construction Multifamily Homes) and its standards with its implementation on residential projects around the world. Additionally, it focuses on how LEED V4.1 (BD+C Multifamily Homes) can be adopted and used to convenient the local site of high-rise residential projects in Duhok city. As to attain the objectives of the paper, the methodology includes analyzing and reviewing the criteria and codes of sustainable site in high-rise residential projects and the sustainable rating systems by studying and searching the published scientific researches and literatures. The research is identifying and considering the codes and standards as guideline from LEED sustainable rating system. The information has been analyzed qualitatively and achieved through a collection of researches on subject matter such as; text books, scientific journals, articles, published papers, internet sources and analyzing, observing, interviewing and evaluating existing case study in the city.

Data have been collected from existing case study (Avrocity) in Duhok city and evaluated according to LEED V4.1 (BD+C Multifamily Homes) sustainable rating system through a checklist that includes various points related to site of selected project. The needed data have been collected according to site design such as open green spaces, transportation, location, land use, diverse activities, services, heat island, light pollution and rainwater management etc. This evaluation came up with modified sustainable standards and codes for the site of project to be a guideline for the future sustainable site of high-rise residential projects in Duhok city.

\section{Sustainable Concept}

The concept of sustainability is one of the most used concepts today. It has started to be used widely especially since the 1980s. The word "sustainability" is derived from the Latin word "Sustinere". Although it has been used in many different meanings in dictionaries, essentially it is used as sustaining, providing, maintaining, supporting and existing (Vujošević, 2012). Sustainable concept is defined as a participatory process that allows the judicious use of social, cultural, scientific, natural and human resources (Gladwin et al., 1995). It will be wise to examine green buildings and their benefits, which is an increasingly important issue. It can be encountered the following topics with green buildings; ensuring energy efficiency, ensuring water efficiency, ensuring waste management, regulations created due to green codes and certifications, ensuring indoor quality, ensuring material selection (Roper and Beard, 2006). It is possible to say that, basically, the sustainability concept characterizes the development and aims to ensure the 
continuation of the development in the future (Sencar, 2007). The concept is being used more often and in a wider area every day.

\subsection{Sustainable High-Rise Residential Buildings}

The housing is simply defined as the enough space that protects the person from outside factors and provides with the necessary physiological and psychological needs according to efficiency design (Ali, 2009).

High-rise residential building is a type of housing that has multi-dwelling units built on the same land. This type of housing has become popular each year in urban area due to the increasing cost of land. There are several common facilities provided in high-rise residential building (Wahab, et al., 2016). Residential complexes consist of special elements that cannot be dispensed on. These basic elements are; residential areas, services, ways and density. Sustainable buildings are buildings built by the efficient use of resources within the framework of ecologically-based principles to create a healthier environment (Chen and Chambers, 1999). To ensure the effective application of sustainable buildings, the engineering and architectural practices must take the three pillars of sustainability in consideration which are; environmental, social and economic (Dusek, 2006). Today, these structures are targeting ecological sustainability which have great importance. Table 1 illustrates the Green Buildings Revolution according to Darko and Chan (2016).

\section{Table 1: Green buildings (Darko and Chan, 2016)}

- As part of the global response; they are aware of the effects of human activities on climate change - They are referred to as advanced technology developments; which are aware of the importance of buildings in terms of environment, human health and considering this concept

- They prefer renewable energy sources

- They take advantage of solar energy

- They are successful in producing the energy required for their functions

- They find application areas by using concepts such as reuse, build, operation, design, transport, maintenance, material selection and better residence

\subsection{Sustainable Site design}

It is necessary to make laws and regulations regarding agencies to create sustainable sites. Arrangement of various areas and facilities takes place based on large facility types. To address some points on the most sustainable sites, the following can be encountered;

- Reducing the demand for transportation

- Recycling of contaminated or degraded areas

- Minimizing the effects caused by light pollution

- Preserving water quality by managing rainwater and ecosystem (Alam and Haque, 2016).

\subsection{Sustainable Rating Systems}

Around the world there are hundreds of sustainable rating tools, which are very important for evaluating buildings in various aspects of sustainable development and designed for various projects types. LEED is a shortcut of Leadership in Energy and Environmental Design, which was established by United States Green Building Council (USGBC) in United States of America. It was the second assessment tool performed 
globally after BREEAM. LEED Version 4.1 was released in April 2019. The buildings which has LEED certification is more efficient in energy use than national average by $25 \%$ to $30 \%$. Particularly, the buildings with high rated LEED certification such as Platinum and Gold certification are performing even better than the buildings LEED non-certified by $45 \%$ (Kim et al., 2017).

\section{Duhok City}

The meaning of the city name is two lumps or small village. The governorate of Duhok was established in 1969 and the city of Duhok became the governorate center. Duhok governorate is divided into six provinces including Duhok, Zakho, Semel, Sheikhan, Amedy and Akre. (General Directorate of Urban Planning, 2010). The location of Duhok is strategic since it has boundaries with Turkey and Syria. It is well recognized by its topography. The city take place in wide valley between Bekher Mountain from north and Zawa Mountain from south, because of this typography urban growth is toward east and west directions (Mohammed, 2013; Ibrahim, 2017). The climate is moderate according to the south and middle parts of Iraq. The highest temperature degrees are recorded in July and August, in daytime can rise to $45^{\circ} \mathrm{C}$ while, in January and February the temperature degrees are low and can decrease to $0^{\circ} \mathrm{C}$ in daytime (General Directorate of Municipalities, 2018). Duhok city is categorized as highly urbanized because of rapid growth in population in previous years, yet it is noted as mid-sized city. Hence, a lot of sectors in city facing challenges because of this phenomenon (Hassan and Kotval-K, 2019). Figure 1 shows the population growth through years (Directorate of Statistics, 2018).

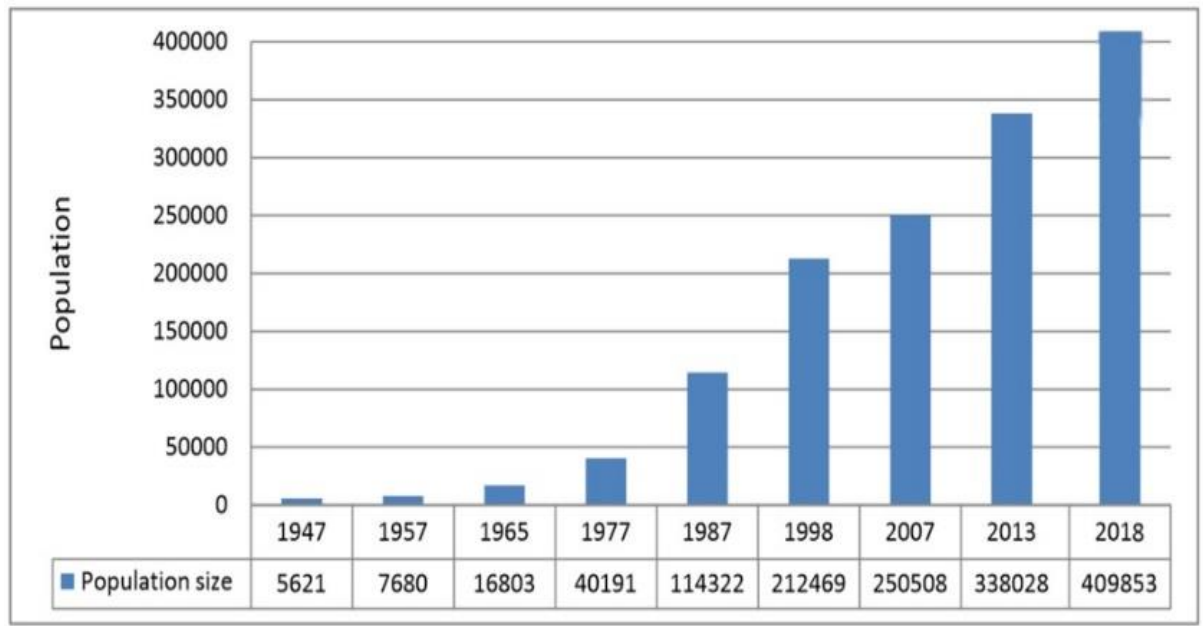

Figure 1: Population growth of Dubok city (Directorate of Statistics, 2018)

\subsection{Housing Regulations in Duhok City}

Housing planning comprehensive mean an incorporated system including land, technical and social infrastructure with housing units (Al-Issawi, 1996). In 1982, Iraqi State Commission of Housing with collaboration of Pol Service developed surveys and studies 
of a schema in 1977 to set the scheme of housing standards to be regulations and criteria of residential areas and housing construction. After these searches and studies, Iraqi housing regulations and standards did not improve or develop in details, unless some inner decisions from province directory to suit the current situation. Additionally, these previous studies were able to solve problems and create a convenient living criterion of that time, but it is not logical to use same standards after approximately 40 years because the modern technology and way of living has been changed. However, the current housing standards in Iraq does not mentioning the high-rise construction and the reason for it is that the studies were on multi floors housing up to four floors which it was the maximum floor number and it considered as mid-rise construction. According to references in General Directorate of Urban Planning in Duhok, from ten floors and above is considered as highrise residential building. In present time, there are numerous projects of high-rise residential buildings in Duhok to cover the demand of citizens to obtain an apartment, but the lack of regulations led these projects to lack of appropriate standards of living quality. From here the question of this study came to light by focusing on the largest and most important sector of the city and deliver a comprehensive idea of what is the problem and what can be done to recommend solutions for the current situations in residential sector of Duhok city in general and site of high-rise residential projects in specific.

\subsection{Duhok in the Context of Sustainability}

Since 2007, Duhok introduced to a new housing structure approach which is vertical housing construction. It is commonly consisting of four properties per one floor with floors number of ten floors and in some projects, it may rise to fifteen, twenty or even twenty-five floors. Such a concept gain popularity by the residents of the city because it was more affordable with new social and technical infrastructures, and because the city is developing continually the value of residential lands become even more expensive for whom wish to own a plot of land to build on it. To improve the awareness of stakeholders about sustainability concept by considering the importance of value more than the cost and rethink of long-term instead of short terms solutions to limit the problems. As well as, lack of sustainable measurement codes and tools in Duhok city is a barrier to implement sustainability.

\section{Avrocity Project}

Avrocity residential project is located to the west of Duhok city, near Tenahi district that is far from center of Duhok city about 6 kilometers with more than 23300 residents. The total area of the project is about 81.7 hectares with total of 4532 apartments. The apartments have four categories in accordance to the spaces and dimensions, as well as the projects includes 93 villas. Avrocity project consists of many social and technical infrastructures that are very important for its residents' comfort and needs. The project started the construction in 2007 through different construction phases. The residential buildings have various floors height such as 8, 9, 10, 12 and 14 floors (Avrocity administration, 2018). Figure 2 displays the location of Avrocity project within Duhok city. 


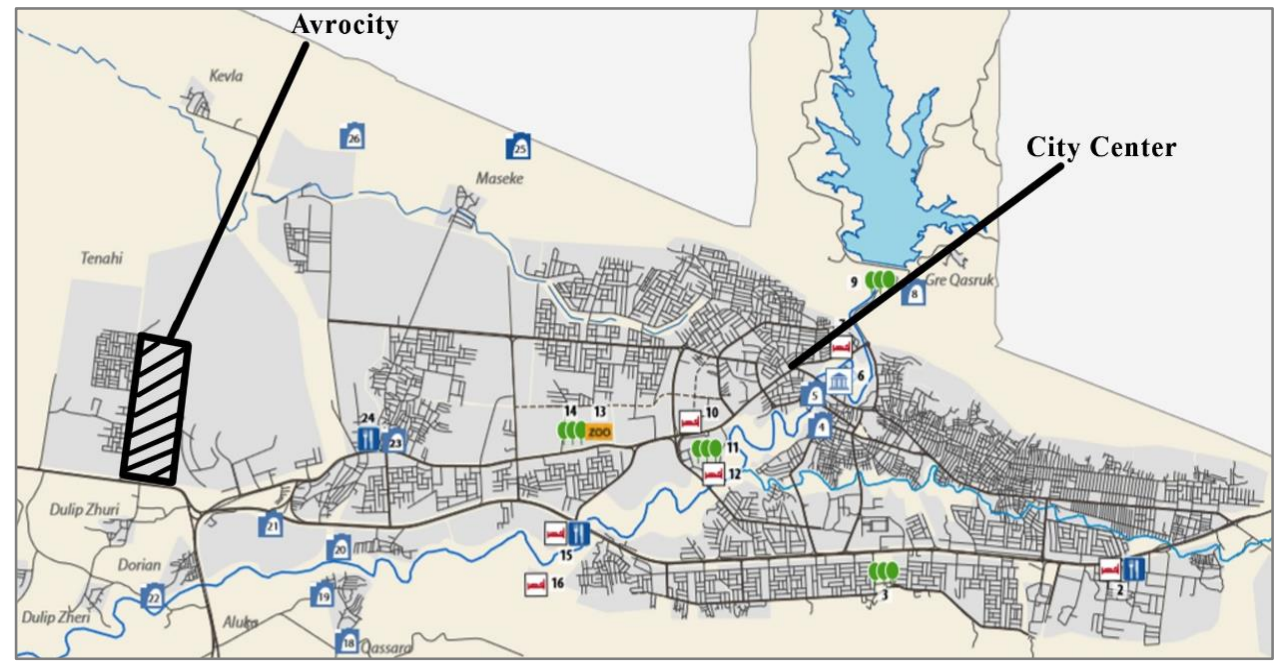

Figure 2: City center of Dubok and Avrocity project location within the city (General Directorate of Urban Planning, 2010)

\subsection{Evaluation of Location and Transportation}

The site of Avrocity as high-rise residential project has been evaluated in accordance to Location and Transportation credit of LEED Version 4.1 for Building Design and Construction of Multifamily Homes rating system.

Sensitive Land Protection: The site is not a unique farmland, prime farmland or an importance land for local. As well as, it is not placed in an area with flood hazards. The site is not a habitat or homeland for ecological communities. There is no water bodies or wetlands around the project. The site can meet the second option of this credit which can take one point from this credit.

High Priority Site: The site does not meet this point, because it was not located on an infill location within a historical district neither on a brownfield where the groundwater or soil pollution has been identified.

Surrounding Density and Diverse Uses: LEED rating system is recommending some criteria for surrounding density, which are shown in Table 2 (USGBC, 2019).

Table 2: Points for surrounding density in a project (USGBC, 2019)

Combined Density Separate Residential and Nonresidential Densities Points

$\mathrm{m}^{2} /$ Hectare of buildable land Residential (DU/hectare) Nonresidential (FAR)

$\begin{array}{lccc}5,050 & 17.5 & 0.5 & 2 \\ 8,035 & 30 & 0.8 & 3\end{array}$

DU $=$ dwelling unit

$\mathbf{F A R}=$ floor-area ratio

In Avrocity site, the residential density (dwelling per hectare) of project is about 56.6, which is exceeding the recommended standard. Formula 1 below can be used to calculate residential density; 
Residential density $=\frac{\text { total number of dwellings (DU) }}{\text { total area of land (hectare) }}=\frac{4,625}{81.7}=56.6$ (DU/hectare) [formula 1] The nonresidential density (floor area ratio) of project is about 0.15 , which is lesser than both possible points. Formula 2 below can be used to calculate the nonresidential density; Nonresidential density $=\frac{\text { gross floor area }\left(\mathrm{m}^{2}\right)}{\text { total area of land }\left(\mathrm{m}^{2}\right)}=\frac{125,388}{817,812}=0.15(\mathrm{FAR}) \quad$ [formula 2] The project does not obtain any possible points from surrounding density credit. The diverse uses for the residential project are very important and useful for the residents and environment because it reduces the distance traveled by vehicle, promote transportation efficiency and walkability. Recommendation criteria for diverse uses by LEED assessment tool are shown below in Table 3 (USGBC, 2019).

Table 3: Points for diverse uses in a project (USGBC, 2019)

\begin{tabular}{cc}
\hline Multifamily: Uses & Points \\
\hline $4-7$ & 1 \\
$\geq 8$ & 2 \\
\hline
\end{tabular}

Avrocity residential project obtained eleven use types in four categories and these uses are within 800 meters radial walking distance from main entrance of residential buildings. Project obtained eleven use types in four categories as shown below in Table 4.

Table 4: Obtained use types in different categories within Avrocity project

\begin{tabular}{ll}
\hline Categories & Use Types \\
\hline Food retail & 1- Supermarket \\
\hline Community-serving retail & 2- Pharmacy \\
& 3- Technology store \\
\hline Services & 4- Family entertainment venue (sports) \\
& 5- Hair care \\
& 6- Laundry \\
& 7- Restaurant \\
\hline Civic and community facilities & 8- Education facility (K-12 school) \\
& 9- Medical clinic \\
& 10- Police and fire station \\
& 11- Public park \\
\hline
\end{tabular}

Figure 3 is illustrating that all use types are reachable according to the recommended criteria of LEED. Three residential buildings are highlighted in different locations within the site to show the radial walking distances from the main entrance of the buildings to the different use types of buildings

In result, Avrocity can obtain two points from this credit, since it provides eleven use types in four categories which is a LEED standard. 


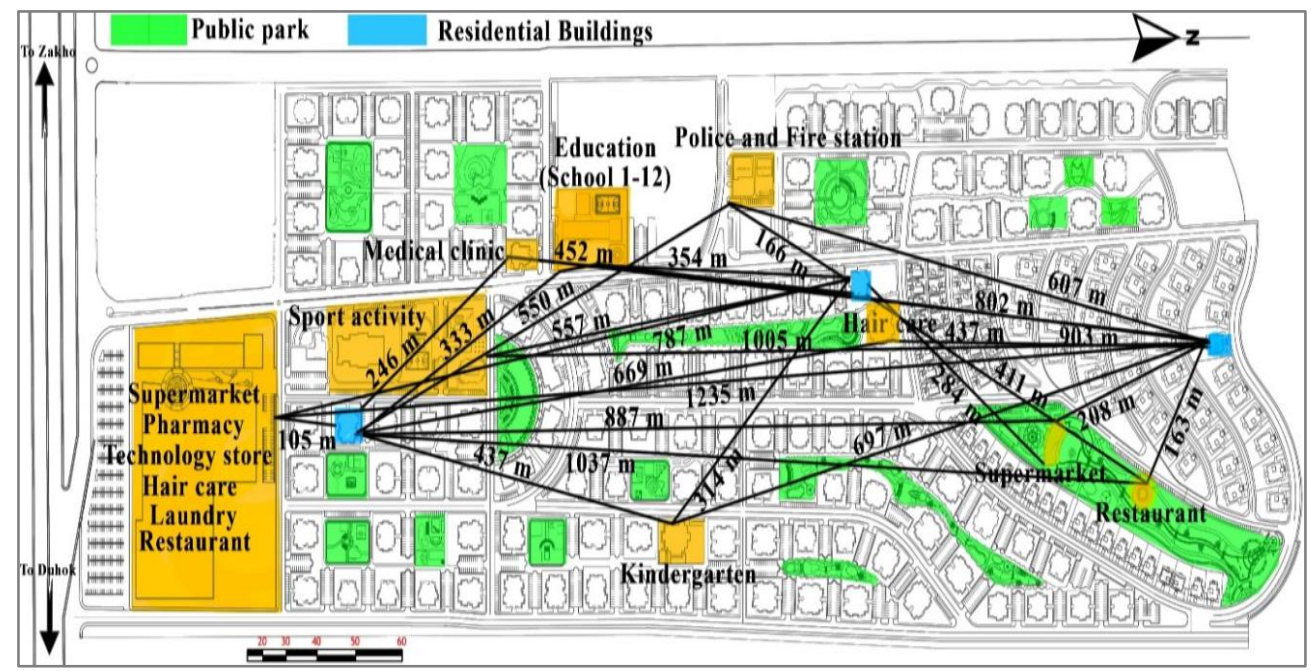

Figure 3: Radial walking distances of 3 residential buildings in different locations (Dhuoki, 2020)

Access to Quality Transit: In this project, the public transportation is not in sufficient level to cover the residents' needs of daily trips. There are some mini buses which are passing by the city while going to Tenahi district, but these mini buses do not have a particular schedule. The only transportation method within project is taxi. It is not possible to obtain any possible points from this credit.

Bicycle Facilities: Avrocity is not able to obtain any possible points from this credit, because the project does not provide any bicycle facilities which means there is no bicycle parking areas and lanes.

Reduced Parking Footprint: The city has 462 dwelling units with 3942 car parking spaces, which means 0.9 car parking space per dwelling unit. According to General Directorate of Urban Planning in Duhok city, the project must provide 6938 car parking spaces for 4625 dwelling units, which means 1 car park space per dwelling unit and 0.5 car park space per dwelling unit for visitors, which is in total 1.5 car parking space per dwelling unit, which is not applicable here. Consequently, Avrocity is reducing the car parking footprint up to $43.18 \%$ compared to local standards while LEED is recommending at least $30 \%$, which qualifies it to obtain one point from this credit. Formula 3 below explains the car parking spaces reduction percentage in accordance to the following data:

Local Standards Parking Number (LSPN)

Existing Parking Number (EPN)

Parking reduction $=\frac{\mathrm{LSPN}-\mathrm{EPN}}{\mathrm{LSPN}}=\frac{6,938-3,942}{6,938}=0.4318 \times 100=43.18 \%$

[formula 3]

Electric Vehicles: This advanced technology is new and not available in the country in general and Duhok city in specific which is apparently not applicable in the project. The project is not able to obtain any possible points from this credit.

\subsection{Evaluation of Sustainable Sites}

As previous credits the site of project has been evaluated in accordance to LEED Sustainable Sites credit. The aim is to determine to which level the site is sustainable and 
can meet LEED criteria requirements.

Construction Activity Pollution Prevention: Avrocity save or protect the soil from erosion to reuse it in the other places of project. There is no silt fence around construction boundaries to prevent runoff velocity and distribution of waste materials around the construction site for protection of pass by cars and pedestrians from any dangerous construction activities. Figure 4 shows the construction activities pollution in the project site.

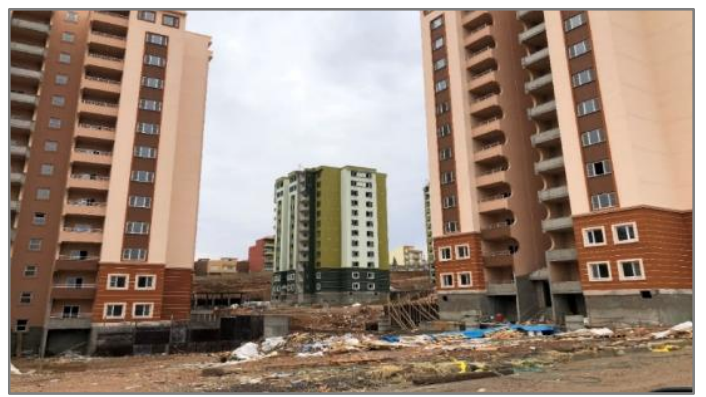

Figure 4: Construction activities pollution in project site (Dhuoki, 2020)

Site Assessment: The project gives importance to the topography of site by designing and constructing in respect to the topographic features, contour line levels and sloped areas. It has an access to clean water network but it does not provide any mechanism or system regarding collection of rainwater and reusing it for irrigation purposes. It has a very good implementation concerning the pervious surfaces and impervious surfaces to prevent water runoff. The buildings are exposed to sun directly which means no any eaves or shading elements above the windows installed to prevent the hot summer sun. Likewise, there are no pergolas or big trees to provide shading to residents in public spaces such as public parks and entertainment places as shown in Figure 5.

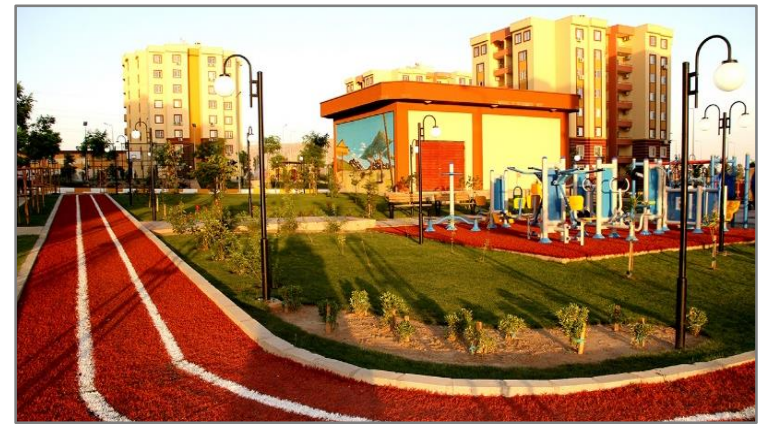

Figure 5: Buildings and public spaces exposure to sun in Avrocity project (Dhuoki, 2020)

The residential buildings coated with light colors to prevent heat absorption and the surfaces are sufficient in terms of green areas covered which means the conservation of resident's thermal comfort from negative impact of urban heat island. The project paid attention to temperature of Duhok city which is hot summer and cold winter by designing residential buildings with insulation on exterior walls and double-glazed windows to 
prevent heat exchange between inside and outside of the buildings. The vegetation types are mainly consisting of palm tree, pine tree, arborvitae tree, shrubs, etc. The project land does not contain any threatened species or invasive vegetation species. Overall, the view is pleasant for residents of the project because there are many green areas and trees which is beneficial for psychology of users. In result, Avrocity does meet most of the above features, for that it is qualified to obtain one point from this credit.

Protect or Restore Habitat: Avrocity is built on greenfield which means there is not any previously disturbed soil. As well as, the soil that have been removed due to construction activates, restored to serve for vegetated areas in project. The vegetation that have been used in project site are native and appropriate for design intentions, climate and conditions of site. In result, it can obtain one possible point from this credit because site meets with most of the criteria.

Open Space: Avrocity is providing open and green spaces up to $247,951 \mathrm{~m} 2$ of total area $817,812 \mathrm{~m} 2$ of project land (building footprint included). Open and green space areas as percentage to the total land project (building footprint included) is $30.32 \%$ that is above the LEED's recommended percentage which is 30\% as minimum. According to LEED $25 \%$ as minimum of the $30 \%$ open and green space areas must be vegetated of two or more species of plants. In Avrocity case $59.48 \%$ of total open and green spaces are planted and it create visual pleasant. All open and green space areas are paved and oriented for pedestrians. Moreover, these areas have sitting spaces with entertainment and outdoor fitness equipment to encourage physical activities for better public health and environment. The project can collect one possible point from this credit.

Rainwater Management: According to LEED minimum percentage of permeable areas to total land area is $50 \%$ to avoid water runoff. In Avrocity, vegetated areas have local species planted and pavements with floor of car parks covered with open paves material, together as permeable areas consist of $42.72 \%$ of total land area and it is below minimum LEED requirement. It is not able to obtain any point from this credit.

Heat Island Reduction: The hardscape in the project is non-roof hardscape which means pergolas over hardscape or shading elements cannot be found. Hence, the entertainment areas, pavements, car parks, etc. do not have any roof, canopies or big trees to provide shading. Also, the materials have been used for hardscape is mostly concrete which is an absorptive material. The project is not qualified to collect any points from this credit.

Light Pollution Reduction: To evaluate the light pollution of outdoor spaces LEED is recommending backlight, uplight and glare (BUG) method. Avrocity outdoor lights are cobra head lights and these lights are unshielded which are the reason to create light pollution, providing trespass to residential buildings and glare to the eyes of pedestrians, resulting visual discomfort and unsafe environment. According to LEED criteria the shielded lights are compulsory to not provide any unwanted light. Outdoor lights in the project are high pressure sodium (HPS) bulbs, which are less energy efficient according to modern light such as light emitting diodes (LED). Outdoor lights in project are providing uplight which is creating unclear vision of the night sky. There is trespass on the areas which lighting is not necessary such as on windows of apartments. High glare is providing visual discomfort for occupants in entertainment areas, on streets and parking areas. Avrocity is not qualified to obtain any points from this credit. Figure 6 shows the outdoor light and its pollution. 


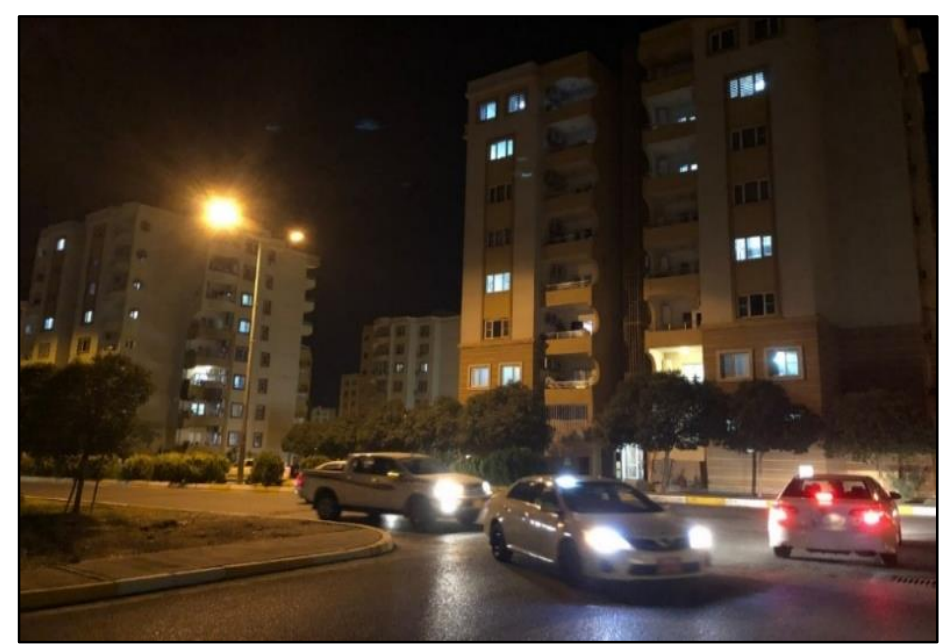

Figure 6: Outdoor light in Avrocity project (Dhuoki, 2020).

\section{Results}

There are various results of Avrocity project and in some LEED credits which obtained maximum points. The project had difficulties in few credits such as Bicycle Facilities credit, it failed to collect any possible points from this credit. It is important to shed light on some of LEED criteria such as Electric Vehicles, this technology is very advanced system and it is newly introduced to the world by developed countries which mean such a technology in a developing country as Iraq is hard to be implemented and considered because the country as whole and more particular Duhok city is lacking of some basic architectural criteria. Construction Activity Pollution Prevention is prerequisite credit, for that there is no possible points to obtain, in this spot Avrocity could not meet this credit. The project collected 7 points from total of 24 possible points of the credits, obviously it is a poor scoring and it is not sustainable enough. Resulting that the project has its own features of architectural and construction designs in respect of sustainable criteria regardless to which level these projects are meeting sustainable standards as shown in Table 5 and Table 6.

Table 5: Results of Avrocity according to location and transportation (Dhuoki, 2020)

\begin{tabular}{lcc}
\hline Location and Transportation & Possible Points & Avrocity \\
\hline 1- Sensitive Land Protection & 2 & 1 \\
2- High Priority Site & 1 & 0 \\
3- Surrounding Density and Diverse Uses & 5 & 2 \\
4- Access to Quality Transit & 3 & 0 \\
5- Bicycle Facilities & 1 & 0 \\
6- Reduced Parking Footprint & 1 & 1 \\
7- Electric Vehicles & 2 & 0 \\
Total Points & $\mathbf{1 5}$ & $\mathbf{4}$ \\
\hline
\end{tabular}


Table 6: Results of Avrocity according to sustainable sites (Dhuoki, 2020)

\begin{tabular}{lcc}
\hline Sustainable Sites & Possible points & Avrocity \\
\hline 1- Construction Activity Pollution Prevention & Prerequisite & $(\mathrm{x})$ \\
2- Site Assessment & 1 & 1 \\
3- Protect or Restore Habitat & 1 & 1 \\
4- Open Space & 1 & 1 \\
5- Rainwater Management & 3 & 0 \\
6- Heat Island Reduction & 2 & 0 \\
7- Light Pollution Reduction & 1 & 0 \\
Total Points & $\mathbf{9}$ & $\mathbf{3}$ \\
\hline
\end{tabular}

\section{Conclusion \& Recommendations}

Duhok city has challenges in residential sector which there is demand on housing units annually. To overcome shortage of housing units that growth of population is causing, one of the solutions is to construct the high-rise residential projects. However, most of these projects are unable to meet the standards and requirements of comfortable daily living for its residents. Based on literature studies, the sustainable high-rise residential projects as comprehensive procedures are very important to offer better built environment for the users. To achieve sustainability, there are many sustainable assessment systems around the world which offers many options to establish sustainable and beneficial environment. One of the most popular and internationally used is LEED sustainable rating tool. The reason that LEED considered a very effective sustainable rating system is the ability of this tool to cover a comprehensive approach of construction sector. Duhok city can borrow LEED sustainable rating system and use its standards requirements to be a base for its residential sector, while these standards can be modified to meet that local conditions and needs of native population. Duhok city can create its own sustainable assessment system to create flexibility and acceptance to the stakeholders and users by time and enough experiences. The results of this study demonstrated that, the sites of the project do not meet the concept of sustainability. The results also showed that Avrocity could not obtain most of the LEED rating system criteria. Concluding that there are no rigid and efficient standards requirements to lead the site of high-rise residential projects of the city. As well as, project site has difficulties to meet sustainable criteria and the traditional architectural designs are not helping the economic and social conditions of the occupants neither improving the quality of the city environment. Thus, sustainable site and the site that can provide more services within walking distance, can enhance the public health of the users and preserve the environment of the city by reducing the dependency on automobiles which are the main source of greenhouse gas emission. Sustainability can be a key point for Duhok city and its population because it is considered as a long-term solution which is providing high quality living standards, stable economy, better social interactions and clean built environment. Therefore, sustainability is not a luxury method but it is a solution for many issues in the city such as shortage of electricity, shortage of water, kerosene dependency, vehicle dependency, etc.

Recommendations: From investigation and evaluation of Avrocity project site as sample of the high-rise residential project in Duhok city, these recommendations are accomplished: - The location of a site is preferable to be either previously developed land or a brownfield 
because such areas are promise zones that can be an opportunity to enhance economic, public health and many other preferences.

- Reducing the surrounding density in high-rise residential projects site because both residential and nonresidential density are linked together and it is very important criteria according to LEED.

- Encouraging high-rise residential projects to provide more public transportations opportunities to decrease the private vehicles dependency and limit the air pollution.

- Provide bicycle infrastructure and network within the site of high-rise residential projects and encourage people to do the physical daily activities.

- It is important to apply the reduction of parking footprint which is effective criteria to limit the usage of cars.

- Introducing the new technology such as electrical vehicles infrastructure and planning for future that can be free of harmful gases.

- Protecting the soil and biodiversity of the site from construction activities, as well as, recycling, managing and reusing the waste materials.

- Designing in accordance to topography features and the climate conditions of Duhok city to provide thermal comfort for the residents.

- Providing the percentage of open and green spaces to the total land area according to LEED requirement, moreover, this standard is significantly recommended because it increase the social activities, public health and environment quality.

- Protect the habitats by using the native plants that are suitable for climate and the site conditions.

- Managing the rainwater to prevent runoffs, the unwanted water on surface of site, improving the water quality and reuse it for irrigation purposes.

- Providing more permeable surfaces on the site by planting more local vegetation species in open and green areas, constructing the pedestrian and parking areas with open paves, as well as, designing green roofs.

- Reducing the negative impact of heat island by designing more roofed hardscape spaces such as parking areas, pavements and entertainment places by applying canopies, pergolas and trees to provide shade.

- Using non-absorptive materials while constructing the surfaces of hardscape spaces to prevent heat storing and releasing.

- Providing solar photovoltaic panel roofs to create shade and in the same time operate as a source of renewable energy by generating electricity for outdoor lights.

- Using modern outdoor lights features and methods such as shielded fixtures and light emitting diodes (LED) luminaire to prevent light pollution and glare, as well as, utilizing lights that are more energy efficient.

\section{Acknowledgement}

This article is generated from the master's thesis entitled Evaluating the Site of HighRise Residential Projects According to LEED Sustainable Rating System: Dubok City, prepared by Riman Dhuoki at the Near East University, under the supervision of Assist. Prof. Dr. Çiğdem Çağnan. 


\section{References}

Alam, S., and Haque, Z. (2016). Fundamental Principles of Green Building and Sustainable Site Design. International Journal of Management and Applied Science, 2(1), 1-5.

Ali, M., and Armstrong, P. (2008). Overview of Sustainable Design Factors in High-Rise Buildings. Council on Tall Buildings and Urban Habitat, 2(1), 1-10.

Al-Issawi, K. (1996). The impact of the residential standards in determining the level of low-cost housing in Iraq. (Master Thesis), University of Baghdad, 32.

Aljenbaz, A.Z., and Çağnan, Ç. (2020). Evaluation of Nanomaterials for Building Production within the Context of Sustainability. European Journal of Sustainable Development, 9(1), 53-65.

Avrocity Administration. (2018). Life in Avrocity. Available online from Avrocity, Retrieved January 05, 2020 from http://www.avrocity.com/.

Chen, J.J., and Chambers, D. (1999). Sustainability and the impact of Chinese policy initiatives upon construction. Construction Management and Economics, 17(5), 679-687.

Darko, A., and Chan, A.P.C. (2016). Critical analysis of green building research trend in construction journals. Habitat International, 57(7), 53-63.

Dhuoki, R. (2020). Evaluating the Site of High-Rise Residential Projects According to LEED Sustainable Rating System: Duhok City. (Master Thesis), Near East University.

Directorate of Statistics. (2018). Kurdistan Region of Iraq Demographic Survey. Demographic survey report. Baghdad: International Organization for Migration.

Dusek, V. (2006). Philosophy of technology: An introduction (Vol. 90). Oxford: Blackwell Publishing.

General Directorate of Municipalities. (2018). Weather in Duhok City. Weather forecasting report. Oslo: Norwegian Meteorological Institute.

General Directorate of Urban Planning. (2010). Master Plan Duhok City. Urban development report. Erfurt: Ingenieurbüro Vössing.

Gladwin, T.N., Kennelly, J.J., and Krause, T.S. (1995). Shifting Paradigms for Sustainable Development: Implications for Management Theory and Research. Academy of management Review, 20(4), 874-907.

Hassan, A., and Kotval-K, Z. (2019). A Framework for Measuring Urban Sustainability in an Emerging Region: The City of Duhok as a Case Study. Sustainability, 11(19), 1-20.

Ibrahim, G.R.F. (2017). Urban Land Use Land Cover Changes and Their Effect on Land Surface Temperature: Case Study Using Dohuk City in the Kurdistan Region of Iraq. Climate, 5(13), 1-18.

Kaplan, D. (2007). Sustainable Design in High-Rise Residential. Council on Tall Buildings and Urban Habitat, 1(2), 14-17.

Kim, H.Y., Shin, M.H., Gu, D., and Kim, H. (2017). LEED, Its Efficacy and Fallacy in a Regional ContextAn Urban Heat Island Case in California. Sustainability, 9(10), 1-11.

Mohammed, A.O. (2013). Evaluation of Multi-Storey Housing Projects in the Context of Sustainability/The city of Duhok. (Master Thesis), University of Duhok Faculty of Engineering and Applied Science School of Planning, 70.

Roper, K.O., and Beard, J.L. (2006). Justifying sustainable buildings - championing green operations. Journal of Corporate Real Estate, 8(2), 91-103.

Sencar, P. (2007). The Relation of Environmental protection and economic growth in Turkey. (Master Thesis), Trakya University, 32.

Shawkat, L.W., Muhy Al-Din, S.S., and Kuzović, D. (2018). Opportunities for Practicing Sustainable Building Construction in Kurdistan Region, Iraq. Journal of Contemporary Urban Affairs, 2(1), 96-101.

United Nations Environment Programme. (2007). Building and climate change: Status, Challenges and Opportunities. United Nation Environment Programmed, United Nation.

United States Green Building Council. (2019). Leadership in Energy and Environmental Design v4.1 for Residential Building Design and Construction Multifamily Homes. Washington, DC: United States Green Building Council.

Vujošević, M. (2012). About sustainable architecture - a definition. Conference of Protection and Restoration of the Environment, Greece, 1-10.

Classification of High-Rise Residential Building Facilities: A Descriptive Survey on 170 Housing Scheme in Klang Valley 
Wahab, S.R.H.A., Ani, A.I.C., Sairi, A., Tawil, N.M., and Razak, M.Z.A. (2016). Classification of high-rise residential building facilities: A descriptive survey on 170 housing scheme in Klang Valley. MATEC Web Conference, 66, 00103. DOI: https://doi.org/10.1051/matecconf/20166600103

Yıldırım, S., Asilsoy, B., and Özden, Ö. (2020). Urban Resident Views About Open Green Spaces: A Study in Güzelyurt (Morphou), Cyprus. European Journal of Sustainable Development, 9(2), 441-450. 